\title{
Comparison of New and Previous Net Energy Metering (NEM) Scheme in Malaysia
}

\author{
Abdul Hafiz Razali, Md Pauzi Abdullah", Mohammad Yusri Hassan and Faridah Hussin \\ Centre of Electrical Energy Systems, Institute of Future Energy, Universiti Teknologi Malaysia, \\ 81310 UTM Skudai, Johor, Malaysia. \\ School of Electrical Engineering, Faculty of Engineering, Universiti Teknologi Malaysia, \\ 81310 UTM Skudai, Johor, Malaysia.
}

*Corresponding author: pauzi@ fke.utm.my

\begin{abstract}
Net Energy Metering (NEM) scheme was introduced in Malaysia in 2016 to replace the previous Feed in Tariff (FIT) scheme. NEM allows electricity consumers to generate, use and export the net excess energy to the grid. For the net excess energy exported to the grid, the consumer will be paid base on the displaced cost per kWh unit. However, after two years of implementation, not many consumers engaged with the NEM scheme as compared to the previous FIT scheme due to the poor financial return. Beginning 2019, new NEM scheme (NEM 2019) is introduced to replace the previous NEM 2016 scheme. This paper will investigate the potential financial return of the new NEM 2019 in term of net present cost (NPC) and electricity cost savings. The analysis is conducted by using HOMER software on three different size of residential customers; large, medium and small. Different photovoltaic (PV) panel sizes ranging from $1 \mathrm{~kW}_{\mathrm{p}}$ to $8 \mathrm{~kW}_{\mathrm{p}}$ were used in the analysis. The results show that the NEM 2019 produced lower NPC as compared to NEM 2016 for most cases.
\end{abstract}

Keywords: Net Energy Metering, Net Present Cost

(C) 2019 Penerbit UTM Press. All rights reserved

Article History: received 1 February 2019; accepted 10 April 2019; published 25 April 2019.

\section{NOMENCLATURE}

\begin{tabular}{|c|c|}
\hline$P_{d, h}^{\text {consump }}$ & $\begin{array}{l}\text { Energy consumption for a resident at } \\
\text { specific hour, h, and specific day, } d\end{array}$ \\
\hline$P_{\text {total }}^{\text {consump }}$ & $\begin{array}{l}\text { Total energy consumption for a resident } \\
\text { in a month }\end{array}$ \\
\hline$P_{d, h}^{\text {generate }}$ & $\begin{array}{l}\text { Energy generation from a resident at } \\
\text { specific hour, h, and specific day, } d\end{array}$ \\
\hline$P_{\text {total }}^{\text {generation }}$ & $\begin{array}{l}\text { Total energy generation for a resident } \\
\text { in a month }\end{array}$ \\
\hline Price $e^{\text {tariff }}$ & Standard domestic tariff based on TNB \\
\hline$D C$ & $\begin{array}{l}\text { Displace cost for RE less than } 1 \mathrm{kV} \\
\text { connection point is } 31 \text { cent per } \mathrm{kWh}\end{array}$ \\
\hline Price consump $^{\text {cons }}$ & $\begin{array}{l}\text { Price of total energy consumption for a } \\
\text { resident in a month }\end{array}$ \\
\hline Price generate $^{\text {gen }}$ & $\begin{array}{l}\text { Price of total energy consumption for a } \\
\text { resident in a month }\end{array}$ \\
\hline$P_{\text {total }}^{\text {net }}$ & $\begin{array}{l}\text { Total net balance of energy } \\
\text { consumption and generation }\end{array}$ \\
\hline
\end{tabular}

\section{INTRODUCTION}

Malaysia is seen to be more serious in increasing the electricity generation from renewable energy resources when the government introduced Feed-in Tariff (FIT) scheme under the Renewable Energy Act in 2011. Under this scheme, the commercial and residential electricity customers can generate electricity from renewable energy and sell all generated energy to the Tenaga Nasional Berhad (TNB), the sole electricity utility in Malaysia. However, the FIT scheme is not sustainable in a long run due to the high cost involved to fund such scheme. Therefore, in 2016 the government introduced net energy metering (NEM), named as NEM2016 in this paper.

Unlike FIT where the customers are being paid for the gross energy generated from PV, NEM only considers the net energy generated. The customer will be paid base on the displaced cost per kWh unit. However, NEM2016 received poor response from electricity customers in Malaysia due to unattractive financial return. The displaced cost for RE less $1 \mathrm{kV}$ connection point is RM $0.31 / \mathrm{kWh}$ [1]. This rate does not benefiting large consumers since they are paying more expensive electricity tariff. To overcome the problem, the government introduced a new NEM scheme in 2019 by setting the pay rate at retail rate per $\mathrm{kWh}$ energy export to the grid.

This paper compares the performance of NEM 2019 against NEM 2016 in term of net present cost (NPC) and electricity cost savings.

\section{NET ENERGY METERING}

2.1 Net Energy Metering (NEM) in selected countries NEM is firstly introduced in 1983 in the USA. Since then, the scheme has been implemented in 55 countries [2]. Each 
of the countries may implement different NEM scheme model based on their needs and practicality.

\subsubsection{Australia}

In Australia, different terminology is used. Net metering is categorized as one type of feed-in tariff. Gross metering is the other type, which is similar to the FIT [3]. In Victoria, the policy is implemented under premium FIT for solar program. All customers from residential, small businesses and community group are allowed to generate electricity from solar energy for up to $5 \mathrm{~kW}$ [4]. Every excess energy unit will be paid at A $\$ 0.60 / \mathrm{kWh}$ [5]. South Australia State implements the policy under the program Solar Feed-in Payment. The customer from residential, small businesses, community building and churches can generate electricity from solar energy. The customer must consumed less than $160 \mathrm{MWh}$ a year [6]. The net excess of electricity generation will be paid at a rate of A\$ $0.44 / \mathrm{kWh}$. Queensland of Australia implements the policy named Solar Bonus Scheme. The customer must consume less than $100 \mathrm{MWh}$ a year [7]. The rate of $\mathrm{A} \$ 0.44 / \mathrm{kWh}$ for excess electricity exported to the grid will be paid to the customer.

\subsubsection{Canada}

In British Columbia of Canada, customers are allowed to generate energy from renewable sources up to $100 \mathrm{~kW}$ [8] and the customer will be paid at a rate of CAD $\$ 0.0999$ for every kWh excess generation [9]. In Nova Scotia, net metering program is offered to residential and businesses. The state allows the generation from wind, solar, hydro and wind up to $100 \mathrm{~kW}$ [10]. For residential, any exported excess electricity to the grid will be credited at a rate of CAD\$0.126. Quebec of Canada offers net metering program to residential, farmers and small businesses to generate energy from wind, solar, hydropower, geothermal and bioenergy up to $50 \mathrm{~kW}$ [11].

\subsubsection{Cyprus}

In Cyprus, net metering program is eligible only for solar energy generated by residential customer. The maximum allowable capacity for customer is $5.2 \mathrm{kWp}$. Any excess generation will be credited based on the five tier block rate electricity tariff and after a year, any excess credit will be reset to zero [12].

Table 1. NEM in other countries

\begin{tabular}{|c|c|c|c|c|}
\hline Country/ State & $\begin{array}{l}\text { Allowable } \\
\text { Technology }\end{array}$ & Allowable Customer & $\begin{array}{l}\text { Allowable } \\
\text { Capacity }\end{array}$ & $\begin{array}{l}\text { Net Excess Generation } \\
\text { (NEG) Rate Price }\end{array}$ \\
\hline $\begin{array}{l}\text { Australia/ } \\
\text { Queensland [3] }\end{array}$ & Solar & $\begin{array}{l}\text { Households, } \\
\text { Small businesses } \\
\text { Consume less than } \\
100 \text { MWh a year }\end{array}$ & $10 \mathrm{~kW}$ & $\begin{array}{l}\text { AUD } \$ 0.44 / \mathrm{kWh} \text { for excess } \\
\text { electricity exported to the } \\
\text { grid }\end{array}$ \\
\hline $\begin{array}{l}\text { Australia/ South } \\
\text { Australia [3] }\end{array}$ & Solar & $\begin{array}{l}\text { Households, } \\
\text { Small businesses, } \\
\text { Community } \\
\text { buildings, } \\
\text { Churches } \\
\text { Consume less than } \\
160 \text { MWh a year }\end{array}$ & $5 \mathrm{~kW}$ & $\begin{array}{l}\text { AUD } \$ 0.44 / \mathrm{kWh} \text { for excess } \\
\text { electricity exported to the } \\
\text { grid }\end{array}$ \\
\hline $\begin{array}{l}\text { Australia/ } \\
\text { Victoria [3] }\end{array}$ & Solar & $\begin{array}{l}\text { Households, } \\
\text { Small businesses, } \\
\text { Community groups }\end{array}$ & $5 \mathrm{~kW}$ & $\begin{array}{l}\text { AUD } \$ 0.60 / \mathrm{kWh} \text { for excess } \\
\text { electricity exported to the } \\
\text { grid }\end{array}$ \\
\hline $\begin{array}{l}\text { Canada/ British } \\
\text { Columbia }\end{array}$ & Renewable energy & $\begin{array}{l}\text { Residential, } \\
\text { businesses }\end{array}$ & $100 \mathrm{~kW}$ & $\begin{array}{l}\text { CAD\$0.0999/kWh for } \\
\text { excess electricity exported } \\
\text { to the grid [9] }\end{array}$ \\
\hline $\begin{array}{l}\text { Canada/ Nova } \\
\text { Scotia }\end{array}$ & $\begin{array}{l}\text { Wind, solar, } \\
\text { hydro and } \\
\text { biomass }\end{array}$ & Home, business & $100 \mathrm{~kW}$ & $\begin{array}{l}\text { CAD\$0.126/kWh for } \\
\text { excess electricity exported } \\
\text { to the grid [9] }\end{array}$ \\
\hline Canada/ Quebec & $\begin{array}{l}\text { Wind, } \\
\text { solar, } \\
\text { hydropower, } \\
\text { geothermal, } \\
\text { bioenergy }\end{array}$ & $\begin{array}{l}\text { Residential, } \\
\text { farmers, } \\
\text { small-business }\end{array}$ & $50 \mathrm{~kW}$ & $\begin{array}{l}\text { Any remaining credits will } \\
\text { be set to zero. No payment } \\
\text { to the customer for energy } \\
\text { excess [9]. }\end{array}$ \\
\hline Cyprus & Solar & Residential [12] & $5.2 \mathrm{~kW}_{\mathrm{p}}[13]$ & $\begin{array}{l}\text { Any remaining credits will } \\
\text { be set to zero. No payment } \\
\text { to the customer for energy } \\
\text { excess [12] }\end{array}$ \\
\hline
\end{tabular}




\subsection{Net Energy Metering (NEM) Malaysia}

In Malaysia, NEM scheme was introduced in 2016 to replace the FIT scheme. Among the objectives of FIT scheme was to facilitate the growth of RE industry. However, the FIT scheme is difficult to sustain as other electrical customers need to fund the scheme through renewable energy fund charge embedded in their electricity bill. It is collected through a surcharge of consumers' electricity consumption at the rate of $1.6 \%$. TNB is only the collecting agent of the fund for the Government. Therefore, NEM is introduced in 2016 to solve these problems.

After two years implementation, NEM 2016 failed to help RE to meet its growth target. One of the main factors is every imported energy to the grid will only be paid at a displaced cost of RM0.31 for per kWh unit, which is not attractive financially. In Malaysia, residential customers are charged based on Tariff A (domestic tariff) [14] as shown in Table 2. The customers are charged at a rate of 21.8 cents $/ \mathrm{kWh}$ for the first $200 \mathrm{kWh}$ and 33.4 cents $/ \mathrm{kWh}$ for the next $100 \mathrm{kWh}$ energy usage. The electricity charge rate increases if they consumed more. If the consumption exceeds $300 \mathrm{kWh}$ per month, they will have to pay 51.6 cents/kWh for the 301th $\mathrm{kWh}$ onwards, which is far higher than the displaced cost for NEM payment. Thus, the NEM scheme may not benefiting the residentials with high electricity consumption. For small customers (less than 200kWh usage per month), they already paying low electricity tariff, thus installing PV may not benefited them financially.

To overcome these weakness in 2018the government introduced the new NEM scheme (NEM 2019). The new scheme came into effect on $1^{\text {st }}$ January 2019.

\subsubsection{NEM2016}

Under NEM2016, the allowable technology is solar energy and it is eligible for residential, commercial and industrial customers. For residential, the allowable capacity is up to $12 \mathrm{~kW}$ for single phase and $72 \mathrm{~kW}$ for three phases. While for commercial and industrial is up to $1 \mathrm{MW}$. The excess generation will be credited into the next billing period at displaced cost. Displaced cost is the average cost of generating and supplying one kilowatt hour of electricity from resources other than renewable resources through the supply line up to the point of interconnection with the RE installation [1]. The maximum roll over period is 24 months and any surplus after 24 months will be forfeited [15]. The details are shown in Table 3.

\subsubsection{NEM 2019}

Small changes have been made under NEM 2019 compare to NEM 2016. The allowable customers are residential, commercial, industrial and agriculture. Next, the excess generation will be credited in next bill period at Tariff A (domestic tariff). The rest still the same as NEM 2016 scheme. The details are shown in Table 4.

Table 2. Tariff A (domestic tariff) [14]

\begin{tabular}{|c|c|}
\hline Tariff Category (kWh) & Unit price (cent/kWh) \\
\hline $1-200$ & 21.80 \\
\hline $201-300$ & 33.40 \\
\hline $301-600$ & 51.60 \\
\hline $601-900$ & 54.60 \\
\hline$>900$ & 57.10 \\
\hline
\end{tabular}

\subsection{Mathematical Formulation of NEM}

This section presents the mathematical formulation for NEM 2016 and NEM 2019.

Table 3. Structure of NEM 2016

\begin{tabular}{|c|c|c|c|}
\hline $\begin{array}{l}\text { Allowable } \\
\text { Technology }\end{array}$ & Allowable Customer & Allowable Capacity & Net Excess Generation (NEG) \\
\hline $\begin{array}{l}\text { Solar } \\
\text { 1. Rooftop of } \\
\text { building } \\
\text { 2. Garage, car park } \\
\text { or similar building }\end{array}$ & $\begin{array}{l}\text { Residential, } \\
\text { commercial, } \\
\text { industrial }\end{array}$ & $\begin{array}{l}\text { Residential- } 12 \mathrm{~kW}_{\mathrm{p}} \\
\text { (single phase) } \\
72 \mathrm{~kW}_{\mathrm{p}}(3 \text { phase) } \\
\text { Commercial and } \\
\text { industrial- } 1 \mathrm{MW}_{\mathrm{p}} \text { or } \\
75 \% \text { of maximum } \\
\text { demand or } 60 \% \text { of fuse } \\
\text { rating or } 60 \% \text { of current } \\
\text { transformer }\end{array}$ & $\begin{array}{l}\text { Any surplus will be credited in } \\
\text { the next billing period at } \\
\text { displaced cost. } \\
\text { The max roll over period is } 24 \\
\text { months. Any excess credit } \\
\text { after } 24 \text { months will be forfeit } \\
\text { [15]. }\end{array}$ \\
\hline
\end{tabular}

Table 4. Structure of NEM 2019

\begin{tabular}{|c|c|c|c|}
\hline $\begin{array}{l}\text { Allowable } \\
\text { Technology }\end{array}$ & Allowable Customer & Allowable Capacity & Net Excess Generation (NEG) \\
\hline $\begin{array}{l}\text { Solar } \\
\text { 1. Rooftop of } \\
\text { building } \\
\text { 2. Garage, car park } \\
\text { or similar building }\end{array}$ & $\begin{array}{l}\text { Residential, } \\
\text { commercial, } \\
\text { industrial, } \\
\text { agriculture }\end{array}$ & $\begin{array}{l}\text { Residential-12kW } \mathrm{k}_{\mathrm{p}} \\
\text { (single phase) } \\
72 \mathrm{~kW}_{\mathrm{p}}(3 \text { phase) } \\
\text { Commercial and } \\
\text { industrial- } 1 \mathrm{MW}_{\mathrm{p}} \text { or } \\
75 \% \text { of maximum } \\
\text { demand or } 60 \% \text { of fuse } \\
\text { rating or } 60 \% \text { of current } \\
\text { transformer }\end{array}$ & $\begin{array}{l}\text { Any surplus will be credited in } \\
\text { the next billing period at retail } \\
\text { rate. } \\
\text { The max roll over period is } 24 \\
\text { months. Any excess credit } \\
\text { after } 24 \text { months will be forfeit } \\
\text { [15]. }\end{array}$ \\
\hline
\end{tabular}




\subsubsection{NEM 2016}

Under NEM 2016, the total energy consumption for a resident in a month, $P_{\text {total }}^{\text {consump }}$, is given by the total of energy consumption for a resident at specific hour, $h$, and day, d, for 24 hours and 30 days. Therefore, $P_{\text {total }}^{\text {consump }}$, is defined as follows:

$$
P_{\text {total }}^{\text {consump }}=\sum_{d=1}^{30} \sum_{h=1}^{24} P_{d, h}^{\text {consump }}
$$

Next, the total energy generation for a resident in a month, $P_{\text {total }}^{\text {generate }}$, is given by the total of energy generation for a resident at specific hour, $h$, and specific day, d, for 24 hours and 30 days. Therefore, $P_{\text {total }}^{\text {generate }}$, is defined as follows:

$$
P_{\text {total }}^{\text {generate }}=\sum_{d=1}^{30} \sum_{h=1}^{24} P_{d, h}^{\text {generate }}
$$

Then, the price of consumption in a month, Price consump, is derived from the total energy consumption for a resident in a month, $P_{\text {total }}^{\text {consump }}$, multiplied with standard domestic tariff, Price $e^{\text {tariff }}$.

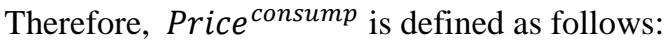

$$
\text { Price } e^{\text {consump }}=P_{\text {total }}^{\text {consump }} \times \text { Price } \text { tariff }^{\text {taif }}
$$

To find the price of energy generation in a month, Price generation $^{\text {, the total energy generation for a resident }}$ in a month, $P_{\text {total }}^{\text {generate }}$, need to multiplied with the displaced cost, DC, or 31 cent for resident. Therefore, Price generate is defined as follows:

$$
\text { Price }^{\text {generate }}=P_{\text {total }}^{\text {generate }} \times D C
$$

Finally, the total electricity bill in a month, Electricity bill, is equal to the difference of between the price of total energy consumption in a month, Price ${ }^{\text {consump }}$, and the price of the total energy generation in a month, Price $e^{\text {generate }}$. Therefore, the electricity bill is defined as follows:

Electricity bill $=$ Price $e^{\text {consump }}-$ Price $e^{\text {generate }}$

\subsubsection{NEM 2019}

For NEM 2019, the calculation of electricity bill is easier compared to NEM 2016. The calculation of $P_{\text {total }}^{\text {consump }}$ and $P_{\text {total }}^{\text {generate }}$ is similar to NEM 2016 as shown in equation (1) and (2) respectively. Then the total net balance between the energy consumption and generation, $P_{\text {total }}^{\text {net }}$, is determined by calculating the difference between the total energy consumption, $P_{\text {total }}^{\text {consump }}$, and the total energy generation, $P_{\text {total }}^{\text {generate }}$, for a resident in a month. Mathematically, it is defined as follows:

$$
P_{\text {total }}^{\text {net }}=P_{\text {total }}^{\text {consump }}-P_{\text {total }}^{\text {generate }}
$$

Finally, the total electricity bill in a month, Electricity bill, is equal to the total net balance of energy consumption and generation, $P_{\text {total }}^{\text {net }}$, multiplied by the

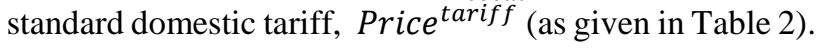
Therefore, the electricity bill is defined as follows:

$$
\text { Electricity bill }=P_{\text {total }}^{\text {net }} \times \text { Price } e^{\text {tariff }}
$$

\subsection{Electricity bill calculation comparison between NEM 2019 and NEM 2016}

This section will show a simple calculation comparison between NEM 2019 and NEM 2016 for residential customer in Malaysia. Assume a residential customer consumed $400 \mathrm{kWh}$ in a month. The resident installed $2 \mathrm{~kW}_{\mathrm{p}} \mathrm{PV}$ panel on the roof, it is assumed that the PV panel generated $250 \mathrm{kWh}$ in a month

Under NEM 2016 scheme, total consumption in a month is multiplied by domestic tariff as in equation (3) to get total price of consumption, therefore the total price of consumption is equal to RM128.60. While, the total price of generation is equal to total generation multiplied by displaced cost as in equation (4), which is RM77.50. Thus, the electricity bill is the price difference between energy consumption and PV generation which is RM51.10.

While under NEM 2019, the different between total energy consumption and total PV generation in one month is considered as net energy consumption and in this case is equal to $150 \mathrm{kWh}$. For the electricity bill, the net consumption is multiplied by the domestic tariff (as given in Table 2). Therefore, the electricity bill is equal to RM32.70.

As expected, the NEM 2019 will result in lower electricity bill compared to NEM 2019. However, these example demonstrate a simple electricity bil comparison between NEM 2016 and NEM 2019 without considering the capital and maintenance cost of PV panel. The next section will presents a more detail comparisons considering various cases.

\section{CASE STUDIES}

This section will investigate the performance between NEM 2019 and NEM 2016 in term of NPC.

\subsection{The System}

Three different sizes; small, medium and large of residential customers will be tested in the simulation. In this paper, small residential customer is assumed to consumed $300 \mathrm{kWh}$ per month, medium residential customers consumed $600 \mathrm{kWh}$ per month and large residential customers consumed $900 \mathrm{kWh}$ per month. Assume that the residents will consume the same amount of energy for every month. All residents will be tested using different size of PV panel which is $1 \mathrm{~kW}_{\mathrm{p}}, 2 \mathrm{~kW}_{\mathrm{p}}$, $4 \mathrm{~kW}_{\mathrm{p}}, 6 \mathrm{~kW}_{\mathrm{p}}$ and $8 \mathrm{~kW}_{\mathrm{p}}$ with initial capital of $\mathrm{RM} 6000$, RM 12000, RM 24000, RM 36000 and RM 48000 respectively. While the maintenance costs are RM 50, RM 100, RM 200, RM 300 and RM 400 per month 
respectively. The initial cost and maintenance cost are assumed at RM 6,000 and RM 50 respectively for every $\mathrm{kW}_{\mathrm{p}}$. The details are shown in Table 6 .

Table 6. The cost for each PV panel size

\begin{tabular}{|c|c|c|}
\hline $\begin{array}{c}\text { PV Panel Size } \\
\left(\mathrm{kW}_{\mathrm{p}}\right)\end{array}$ & Initial Capital (RM) & $\begin{array}{c}\text { Maintenance Cost } \\
(\mathrm{RM})\end{array}$ \\
\hline 1 & 6,000 & 50 \\
\hline 2 & 12,000 & 100 \\
\hline 4 & 24,000 & 200 \\
\hline 6 & 36,000 & 300 \\
\hline 8 & 48,000 & 400 \\
\hline
\end{tabular}

The simulation is conducted using HOMER software. The period of simulation is for 25 years and consider the discounted value of $6 \%$ every year. The load profile for residential and solar radiant data for Skudai, Johor Bahru are used from HOMER. Net present cost (NPC) is used to compare the cost savings between the two NEMs.

\subsection{Results and Discussions}

Figure 1, figure 3 and figure 5 show the accumulated NPC for 25 years for large, medium and small resident respectively, for different PV size and NEM schemes. The NPC for residents without PV is also included in the results as a benchmark. For large resident (Figure 1), NEM2019 provides the lowest NPC result for all PV sizes. The lowest NPC is observed for PV size of $6 \mathrm{kWp}$. These results indicate that for large resident, NEM2019 provides better savings than NEM2016, as illustrated in Figure 2. Also, from Figure 1, NPC for both NEM2019 and NEM2016 is lower than resident without PV for all PV sizes. This indicates that large resident will be benefited financially from PV panel installation for all PV sizes, for both NEM schemes.

For medium resident (Figure 3), the NPC results for NEM2019 and NEM2016 are approximately the same for all PV sizes except for $2 \mathrm{KWp}$ and 4kWp, with NEM2019 provides slightly lower NPC results. However, when comparing the results with resident without PV, both NEM2019 and NEM2016 give higher NPC for $6 \mathrm{kWp}$ and $8 \mathrm{kWp}$ PV size. This shows that the medium resident will not get any saving from PV panel installation if PV size is $6 \mathrm{kWp}$ and above as it will give negative saving percentage, as shown in Figure 4.

Figure 5 shows the NPC comparison results for small resident. The NPC for NEM2019 and NEM2016 are approximately the same for all PV sizes except for $2 \mathrm{KWp}$, in which NEM2016 provides lower NPC than NEM2019. In NEM2016, every net excess of energy will be paid at a displaced cost of 31.0 cent $/ \mathrm{kWh}$. This price is higher than the first block of domestic electricity tariff $(1-200 \mathrm{kWh})$ as shown in Table 2, which is only 21.8 cent $/ \mathrm{kWh}$. For other PV sizes, the capital and maintenance cost dominating the NPC results, thus both NEM schemes give almost similar results. However, the NPC for resident without PV is much lower than the two NEM schemes. The difference becomes more significant as the PV size increases. This is expected since both the capital and maintenance cost are the main contributor to the NPC of both schemes. It can be said that both schemes will not benefit small customers. Increasing the PV size will only make the saving worse, as shown by the negative savings in Figure 6.

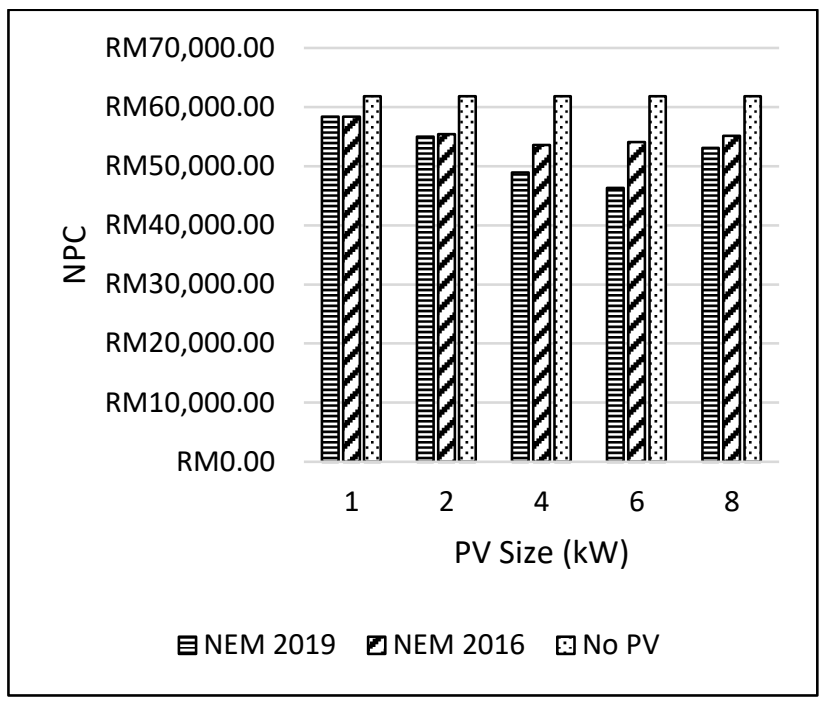

Figure 1. NPC for large resident

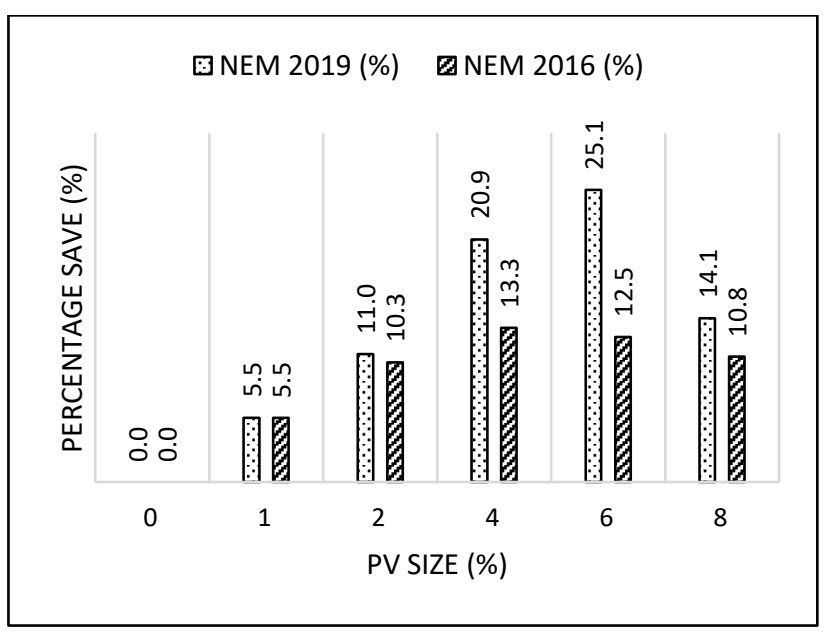

Figure 2. Percentage NPC saving for large resident

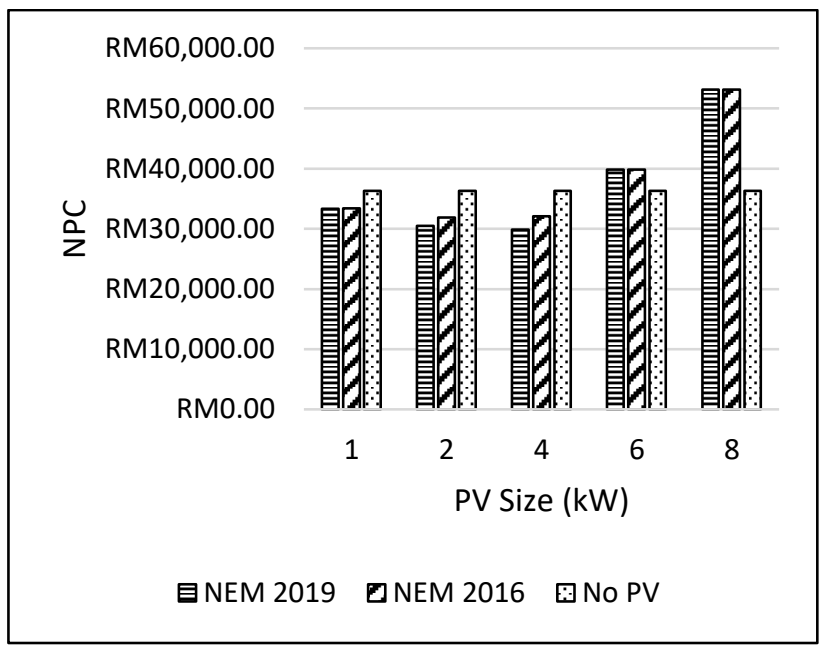

Figure 3. NPC for medium resident 


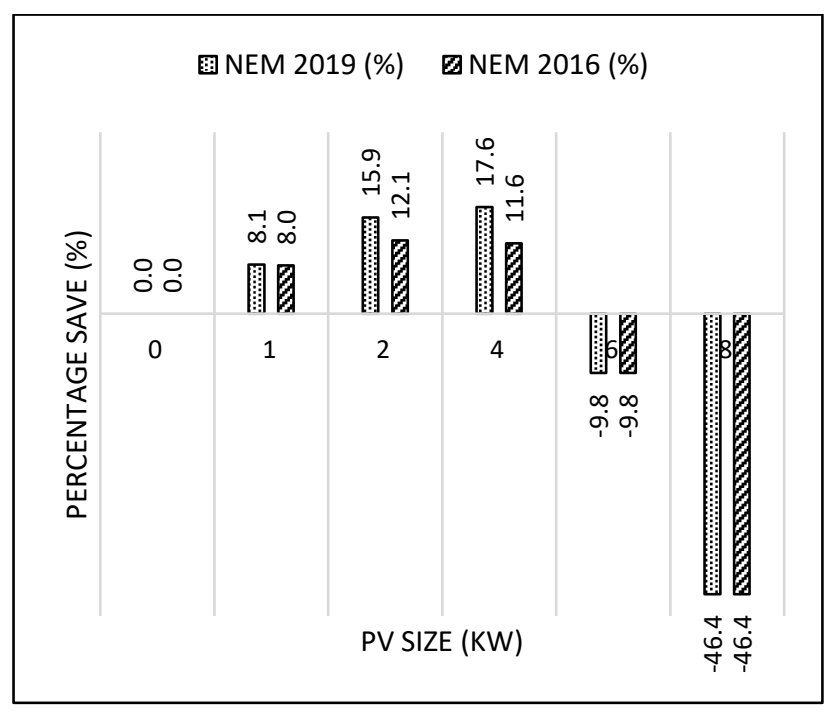

Figure 4. Percentage NPC saving for medium resident

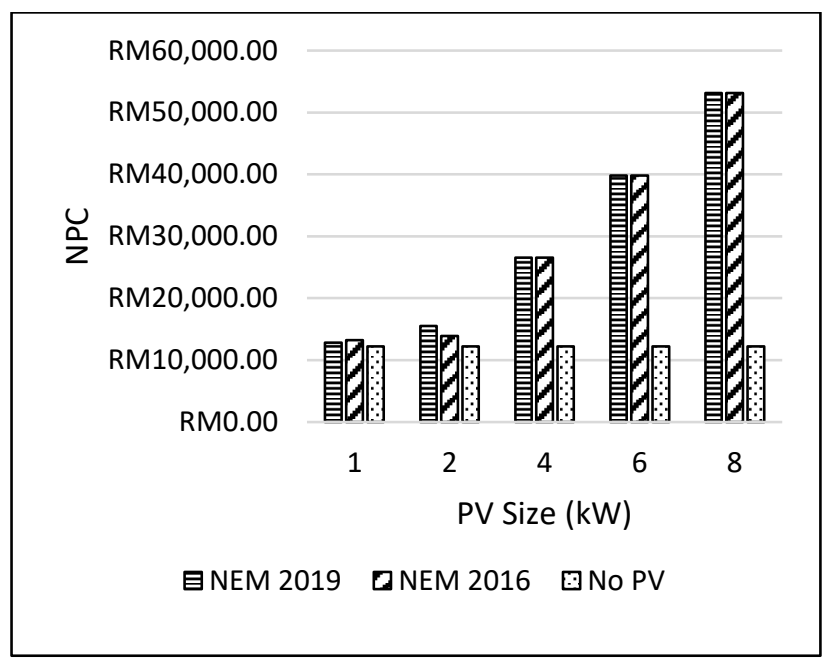

Figure 5. NPC for small resident

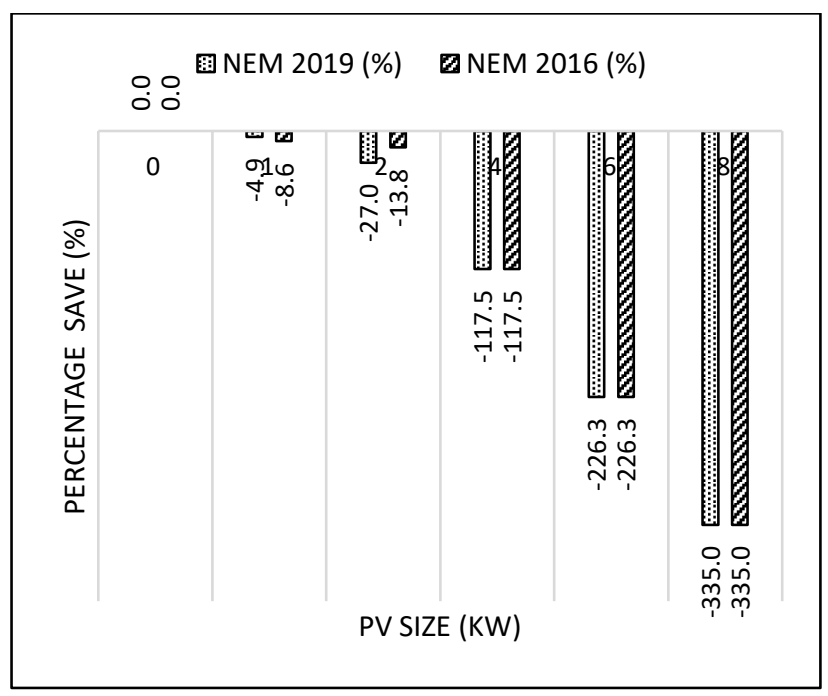

Figure 6. Percentage NPC saving for small resident
In summary, NEM 2019 produces better result in term of NPC savings compared to NEM 2016. Only one case that NEM 2016 produces lower NPC, which is the case of small resident with $2 \mathrm{~kW}_{\mathrm{p}} \mathrm{PV}$ panel. But when comparing the NPCs with without PV, the small resident will not gain benefit of cost saving for both NEM schemes for any PV panel size. For medium residents, selecting the right PV size will give savings to customers for both NEM schemes with NEM2019 provides slightly better savings. For large resident, both schemes will give savings for all PV sizes considered in the analysis, with NEM2019 perform slightly better.

\section{CONCLUSION}

This paper compares the new NEM2019 scheme against the previous NEM2016 scheme in terms of electricity cost savings. From the analysis conducted, NEM2019 offers better cost savings in most cases, hence may attract more electricity consumers to install PV system in their homes compared to NEM2016. However, the cost savings is only apparent for large and some medium consumers. For small consumers, both NEM schemes will not able to provide any savings to justify PV system installation due to the low electricity tariff charged and the high capital and maintenance cost of the PV system.

\section{ACKNOWLEDGMENT}

The authors would like to thank Universiti Teknologi Malaysia for providing financial support to conduct this research (vote no. 17H32).

\section{REFERENCES}

[1] Sustainable Energy Development Authority Malaysia. "Grid Parity \& Displaced Cost". [Online] Available: http://www.seda.gov.my

[2] "Renewables 2017 Global Status Report," REN212017.

[3] A. Zahedi, "A review on feed-in tariff in Australia, what it is now and what it should be," Renewable and Sustainable Energy Reviews, vol. 14, pp. 3252-3255, 2010.

[4] State Government of Victoria. "Premium feed-in tariff". [Online] Available: https://www.energy. vic.gov.au/renewable-energy/victorian-feed-intariff/premium-feed-in-tariff

[5] L. Poruschi, C. L. Ambrey, and J. C. R. Smart, "Revisiting feed-in tariffs in Australia: A review," Renewable and Sustainable Energy Reviews, vol. 82, pp. 260-270, 2018/02/01/ 2018.

[6] Government of South Australia. "Solar feed-in payments". [Online] Available: https://www.sa. gov.au/topics/energy-and-environment/energybills/solar-feed-in-payments

[7] Queensland Government. "Solar Bonus Scheme 44c feed-in tariff". [Online] Available: https://www. dews.qld.gov.au/electricity/solar/installing/benefits/ solar-bonus-scheme

[8] BC Hydro. "Generating your own electricity". [Online] Available: https://www.bchydro.com/ work-with-us/selling-clean-energy/net-metering. html?WT.mc_id=rd_netmetering

[9] J. Fraser, "Net Metering Evaluation Report No. 3," April 30, 20132013. 
[10] Nova Scotia Power. "Enhanced Net Metering ". [Online] Available: https://www.nspower.ca/en/ home/for-my-home/make-your-own-energy/ enhanced- net-metering/default.aspx

[11] Quebec Hydro. "Net Metering Rate Option for SelfGenerators". [Online] Available: http://www. hydroquebec.com/self-generation/docs/depliantmesurage-net.pdf

[12] A. I. Nikolaidis and C. A. Charalambous, "Hidden financial implications of the net energy metering practice in an isolated power system: Critical review and policy insights," Renewable and Sustainable Energy Reviews, vol. 77, pp. 706-717, 2017.

[13] C. Ministry of Energy, Industry and Tourism of Cyprus,. (2017). "Plan for the Production of
Electricity from Renewable Energy Sources for Own Consumption". [Online] Available: http://www.mcit. gov.cy/mcit/mcit.nsf/All/3014DFAB3B5A56F5C22 5811A00337066? OpenDocument

[14] Tenaga Nasional Berhad. "Pricing \& Tariffs". [Online] Available: https://www.tnb.com.my/ residential/pricing-tariffs

[15] Sustainable Energy Development Authority of Malaysia. "Guidelines of Solar Photovoltaic Installation on NEM Scheme". [Online] Available: http://seda.gov.my 